\title{
Pdx1 restores $\beta$ cell function in Irs2 knockout mice
}

\author{
Jake A. Kushner, ${ }^{1,2}$ Jing Ye, ${ }^{1}$ Markus Schubert, ${ }^{1}$ Deborah J. Burks, ${ }^{1}$ Matthew A. Dow, ${ }^{1}$ \\ Carrie L. Flint, ${ }^{1}$ Sanjoy Dutta, ${ }^{3}$ Christopher V.E. Wright, ${ }^{4}$ Marc R. Montminy, ${ }^{5}$ \\ and Morris F. White ${ }^{1}$
}

${ }^{1}$ Howard Hughes Medical Institute, Joslin Diabetes Center, Harvard Medical School, Boston, Massachusetts, USA
2Division of Endocrinology, Children's Hospital, Boston, Massachusetts, USA
3Joslin Diabetes Center, Harvard Medical School, Boston, Massachusetts, USA
${ }^{4}$ Developmental Biology Program, Vanderbilt University, Nashville, Tennessee, USA
${ }^{5}$ Clayton Laboratories for Peptide Biology, The Salk Institute, La Jolla, California, USA
Address correspondence to: Morris F. White, Howard Hughes Medical Institute,
Joslin Diabetes Center, 1 Joslin Place, Boston, Massachusetts 02215, USA.
Phone: (617) 732-2578; Fax: (617) 732-2593; E-mail: whitemor@joslab.harvard.edu.

Received for publication October 18, 2001, and accepted in revised form March 26, 2002.

\begin{abstract}
The homeodomain transcription factor $\mathrm{Pdx} 1$ is required for pancreas development, including the differentiation and function of $\beta$ cells. Mutations in $\mathrm{Pdx} 1$ or upstream hepatocyte nuclear factors cause autosomal forms of early-onset diabetes (maturity-onset diabetes of the young [MODY]). In mice, the Irs2 branch of the insulin/Igf signaling system mediates peripheral insulin action and pancreatic $\beta$ cell growth and function. To investigate whether $\beta$ cell failure in $I r s 2^{-/-}$mice might be related to dysfunction of MODY-related transcription factors, we measured the expression of Pdx1 in islets from young $\operatorname{Irs} 2^{-/-}$mice. Before the onset of diabetes, $\mathrm{Pdx} 1$ was reduced in islets from $\operatorname{Irs} 2^{-/-}$mice, whereas it was expressed normally in islets from wild-type or Irs $1^{-/-}$mice, which do not develop diabetes. Whereas male Irs $2^{-/-} P d x 1^{+/+}$mice developed diabetes between 8 and 10 weeks of age, haploinsufficiency for $P d x 1$ caused diabetes in newborn Irs $2^{-/-}$mice. By contrast, transgenic expression of Pdx 1 restored $\beta$ cell mass and function in Irs2 $2^{-/-}$mice and promoted glucose tolerance throughout life, as these mice survived for at least 20 months without diabetes. Our results suggest that dysregulation of Pdx1 might represent a common link between ordinary type 2 diabetes and MODY.
\end{abstract}

J. Clin. Invest. 109:1193-1201 (2002). DOI:10.1172/JCI200214439.

\section{Introduction}

The insulin receptor substrates (IRS proteins) coordinate many signals during insulin and IGF-1 stimulation, including activation of the phosphatidylinositol (PI) 3-kinase and ERK1/2 cascades (1). Although highly homologous and universally expressed, Irs1 and Irs2 display distinct biological function in mice (2). Irs1 strongly promotes somatic growth and mediates insulin action upon carbohydrate metabolism in skeletal muscle; however, Irs $1^{-/}$mice never develop diabetes, owing to islet hyperplasia and lifelong compensatory hyperinsulinemia (2). By contrast, Irs2 plays a significant role in metabolic regulation, as hepatic gluconeogenesis and lipid metabolism are dysregulated in $\operatorname{Irs} 2^{-/-}$mice (3). Moreover, Irs $2^{-/-}$mice develop progressive $\beta$ cell failure, which exacerbates the peripheral insulin resistance and leads to diabetes (2). The $\beta$ cells in Irs $2^{-/-}$mice display increased apoptosis, especially during weaning, which might contribute to the steady decline of $\beta$ cell mass with increasing age (4). Although moderate hyperinsulinemia compensates for peripheral insulin resistance in young Irs $2^{-/-}$mice, diabetes occurs between 8 and 10 weeks of age, because the diminishing $\beta$ cell content fails to secrete sufficient insulin (2).

Autosomal dominant forms of early-onset diabetes in young adults (maturity-onset diabetes of the young
[MODY]) are linked to mutations in glucokinase or transcription factors that promote normal $\beta$ cell function, including HNF4 $\alpha$ (MODY1), HNF1 $\alpha$ (MODY3), PDX1 (MODY4), HNF1 $\beta$ (MODY5), and NeuroD1/BETA2 (MODY6); MODY2 is caused by mutations in glucokinase, whose expression is regulated by PDX1 (5). The regulation of these transcription factors is complicated, but in certain cases it might be linked to insulin/IGF1 signaling though Foxo1 or $H n f 3 \beta(6)$. Pdx1 plays an important role in islet development and $\beta$ cell function. It is required for pancreas formation during the initial stages of gut development $(7,8)$. In adult mice, Pdx1 promotes the expression of proinsulin, Glut2, and glucokinase, which mediates glucose-sensitive insulin secretion (9-11). Pdx1 also regulates expression of FGFs and their receptors, which might promote $\beta$ cell growth and proinsulin processing via the prohormone processing enzyme PC1/3 (12). Consequently, disruption of $P d x 1$ in murine $\beta$ cells reduces insulin secretion and causes progressive $\beta$ cell loss, which culminates in glucose intolerance and diabetes (13). Moreover, $P D X 1$ is required in adult humans to promote normal glucose sensing and insulin secretion, and mutations in PDX1 represent a risk factor for type 2 diabetes (13-15). In this report, we reveal a close relation between $\mathrm{Pdx} 1$ and Irs2, which suggests that dysregulation of Pdx1 by genetic or functional mechanisms might be a com- 
mon element in autosomal early-onset (MODY) and common type 2 diabetes.

\section{Methods}

Mice. Irs1 knockout (2), Irs2 knockout (2), $P d x 1$ knockout (8), and wild-type $P d x 1$ transgene (16) mice were maintained on a mixed C $57 \mathrm{BL} / 6 \times 129 \mathrm{~Sv} \times$ Black Swiss background. Genotyping of animals was done by PCR as previously described $(4,16)$. Male mice were used to characterize adult glucose homeostasis phenotypes and pancreatic pathology. Male and female $\operatorname{Irs} 2^{+/-P} d x 1^{+/-}$ intercross newborn pups were grouped together, as no sexual dimorphism was apparent in neonatal glucose homeostasis (data not shown). Random-fed glucose and insulin measurements were performed as previously described (4). Intraperitoneal glucose tolerance tests were performed on mice fasted for 15-16 hours with $2 \mathrm{~g}$ D-glucose per kg body weight as previously described (2). Intraperitoneal insulin tolerance tests were performed on fed mice with $0.75 \mathrm{U}$ human insulin per kg body weight as previously described (2).

Immunobistochemistry. Immunohistochemical localization of antigens and double-label immunohistochemistry were performed similarly to previously described methods (4). Pancreas samples were dissected from fed mice and fixed with Bouin's solution overnight. Fivemicrometer longitudinal sections of paraffin blocks were rehydrated with xylene followed by decreasing concentrations of ethanol, microwaved in $0.01 \mathrm{M}$ sodium citrate ( $\mathrm{pH}$ 6.0) for 20 minutes, and permeabilized with $1 \%$ Triton X-100 in PBS prior to primary antisera incubation. Islet morphometry was performed similarly to the methods previously described (4). The primary antibodies were: guinea pig anti-insulin and rabbit antiglucagon antibodies (Zymed Laboratories Inc., South San Francisco, California, USA) rabbit N-terminal anti$P d x 1$ (from C.V.E. Wright), and mouse anti-BrdU (Roche Molecular Biochemicals, Indianapolis, Indiana, USA). Secondary antibodies were labeled with FITC or rhodamine (Jackson ImmunoResearch Laboratories Inc., West Grove, Pennsylvania, USA).

Islet morphometry. Newborn (postnatal day $[\mathrm{P}] 0.5-1.5$ ) $\beta$ cell area was quantified by acquiring adjacent $\times 10$ images of the entire newborn pancreas from two antiinsulin-stained sections per animal, at least six animals per genotype (male and female were grouped together), with a Zeiss Axiovert microscope (Carl Zeiss MicroImaging, Thornwood, New York, USA). Images were analyzed for area with Improvision Open Lab software density slice software (Improvision Scientific Imaging, Lexington, Massachusetts, USA). For each animal the ratio of $\beta$ cell area to total pancreas area was calculated and reported as mean \pm SEM. Adult $\beta$ cell area was measured by acquiring images from two sets of eight to ten random nonoverlapping images at $\times 10$ of insulin- and glucagon-stained sections from male mice, at least four animals per genotype. Results of $\beta$ cell quantification are expressed as the percentage of the total surveyed area containing cells positive for insulin. Islet density and size were calculated from captured insulin-stained images. Ratios of $\beta$ to $\alpha$ cells were calculated from mean insulin- and glucagon-positive cell areas. Islet proliferation and $\beta$ cell size were examined by injecting 2 - to 3 week-old male mice with 5-bromo-2-deoxyuridine (BrdU; Roche Molecular Biochemicals, Indianapolis, Indiana, USA; $100 \mu \mathrm{g} / \mathrm{g}$ body weight) and performing double-label insulin and BrdU immunohistochemistry on rehydrated Bouin's-fixed paraffin-embedded sections from the mice. Images of each islet per section were acquired at $\times 63$. BrdU-positive $\beta$ cell ratios were calculated as the mean \pm SEM of BrdU-positive $\beta$ cells over total $\beta$ cells per section, two sections per animal, three to four animals per genotype. Size of $\beta$ cells was determined by dividing total $\beta$ cell area by the number of $\beta$ cells examined per section.

$R T$-PCR and Western blotting. Islets were isolated from 6-week-old male wild-type, Irs $1^{-/-}$, and Irs $2^{-/-}$mice with Collagenase P (Liberase HI; Roche Molecular Biochemicals) digestion (17) and total RNA was extracted with Trizol (GIBCO BRL; Life Technologies Inc., Grand Island, New York, USA) and RNeasy (QIAGEN Inc., Valencia, California, USA) columns. cDNA synthesis was performed using the RETROscript kit (Ambion Inc., Austin, Texas, USA) and then TaqMan (Applied Biosystems, Foster City, California, USA) quantitative PCR $\left(50^{\circ} \mathrm{C}\right.$ for 2 minutes, $95^{\circ} \mathrm{C}$ for 10 minutes, followed by 40 cycles of $95^{\circ} \mathrm{C}$ for 15 seconds, $60^{\circ} \mathrm{C}$ for 1 minute) was performed with the ABI Prism 7700 PCR instrument (Applied Biosystems) to amplify samples in triplicate for the $P d x 1, H n f 1 \alpha, H n f 1 \beta$, $H n f 3 \beta$ (Foxa2), $H n f 4 \alpha$, and cyclophillin genes. Primers were as follows: Pdx1 forward, AGGAAAACAAGAGGACCCGTACT; Pdx1 probe, CCTACACCCGGGCGCAGCTG; Pdx1 reverse, CGGGAGATGTATTTGTTAAATAAGAATTC; Hnf1 $\alpha$ forward, TGCGTTCTACAACTGGTTTGC; Hnf $1 \alpha$ probe, AGGCTTCCTCCTTGCGCCGG; Hnf1 $\alpha$ reverse, GGAGgTCCGTTATAGGTGTCCAT; Hnf1 $\beta$ forward, GagGagtgtaACAgGgCAGAatgT; Hnf1 $\beta$ probe, CCTTCCAAAGCCCACGGCCTAGG; Hnf1 $\beta$ reverse, GGACCTCCGTGACCAAGTTG; Hnf3 $\beta$ forward, GAACTCCATCCGCCACTCTCT; Hnf3 $\beta$ probe, TCAACGACTGCTTTCTCAAGGTGCCC; Hnf3 $\beta$ reverse, GCCCTTGCCAGGCTTGT; Hnf4 $\alpha$ forward, ACGTGCTGCTCCTAGGCAAT; Hnf $4 \alpha$ probe, CACACGGCTCATCTCCGCTAGCTCTG; Hnf $4 \alpha$ reverse, TCGAGGATGCGGATGGA; cyclophillin forward, CAGACGCCACTGTCGCTTT; cyclophillin probe, CCTACACCCGGGCGCAGCTG; cyclophillin reverse, TGTCTTTGGAACTTTGTCTGCAA. For each sample, triplicate gene expression values were compared with wild-type islet cDNA dilution standard curves of $\log _{4}$ dilutions (undiluted, 1:4, 1:16, 1:64) performed in triplicate $\left(P d x 1\right.$ threshold cycle $\left(C_{t}\right)=23$, $r^{2}=0.99 ; \operatorname{Hnf} 1 \alpha C_{t}=28, r^{2}=0.96 ; \operatorname{Hnf} 1 \beta C_{t}=29$, $r^{2}=0.88 ; \operatorname{Hnf} 3 \beta C_{t}=27, r^{2}=0.95 ; \operatorname{Hnf} 4 \alpha C_{t}=29$, $r^{2}=0.99$; cyclophillin $\left.C_{t}=21, r^{2}=0.98\right)$. Relative gene product amounts were reported as mean \pm SEM of several animals for each gene compared with cyclophillin (wild-type, $n=4 ; \operatorname{Irs1^{-/}}, n=2$; $\operatorname{Irs} 2^{-/-}, n=5$ ). For 


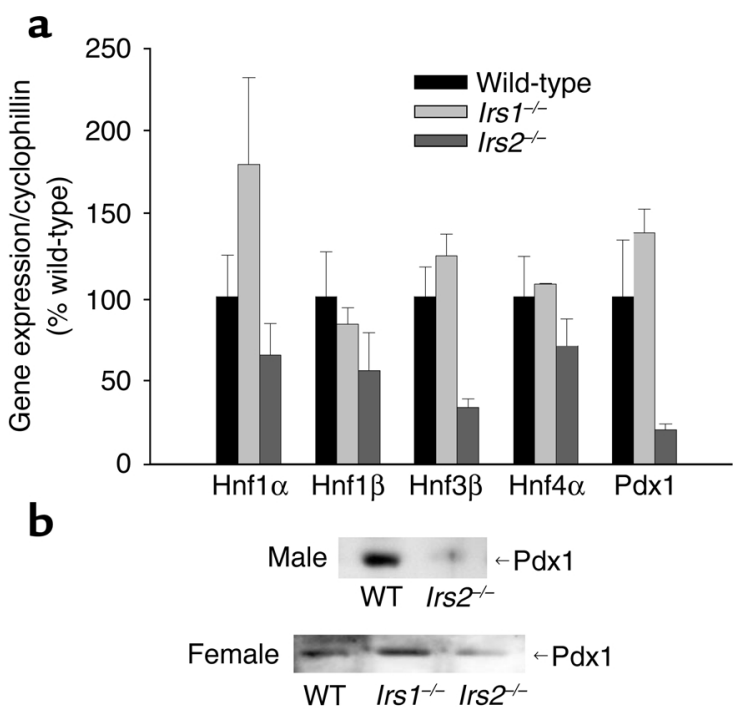

Western blot analysis, SDS protein islet lysates were equalized for loading by total protein assay (Pierce Chemical Co., Rockford, Illinois, USA) run on $12 \%$ SDS-PAGE, transferred to a Protan nitrocellulose membrane (Schleicher \& Schuell Inc., Keene, New Hampshire, USA), incubated with rabbit anti-N-terminal Pdx1 antisera (from C.V.E. Wright) and HRPconjugated goat anti-rabbit antisera, and then treated for enhanced chemiluminescence (NEN Life Science Products Inc., Boston, Massachusetts, USA).

\section{Results}

Pdx1 mRNA levels were measured by RT-PCR in islet extracts from young male mice. Compared with wildtype, Pdx1 mRNA levels were reduced in Irs $2^{-/-}$islets (Figure 1a); similar results were found with agematched female Irs $2^{-/-}$mice (data not shown). Hnf3 $\beta$ (also known as Foxa2) was also reduced in islets from Irs $2^{-/-}$mice, whereas the levels of $\operatorname{Hnf} 1 \alpha, \operatorname{Hnf} 1 \beta$, and $\mathrm{Hnf} 4 \alpha$ were approximately normal in the male Irs $2^{-/}$ mice (Figure 1a). Immunoblotting confirmed that Pdx1 protein levels were low in male and female Irs $2^{-/-}$islets

\section{Figure 1}

Expression of hepatocyte nuclear factors (HNFs) and $P d x 1$ in pancreatic islets. (a) TaqMan RT-PCR of $\mathrm{Hnf} 1 \alpha, \mathrm{Hnf} 1 \beta, \mathrm{Hnf} 3 \beta, \mathrm{Hnf} 4 \alpha$, and $\mathrm{Pdx} 1$ in islets from wild-type (WT) $(n=4), \operatorname{Irs} 1^{-{ }^{--}}(n=2)$, and Irs2 $2^{-1-}$ $(n=5)$ male mice at 6 weeks of age. Data are normalized to cyclophillin gene expression and expressed as mean \pm SEM. (b) Western blots of Pdx 1 in islets from male (top) and female (bottom) mice.

(Figure 1b). By contrast, mRNA levels for Pdx1 and the various hepatocyte nuclear factors were nearly normal in $\operatorname{Irs} 1^{-1-}$ islets at 6 weeks of age, and immunoblotting confirmed that $\mathrm{Pdx} 1$ protein was normal in female Irs $1^{-/-}$mice (Figure $1 \mathrm{~b}$ ). The specific reduction of Pdx1 expression in Irs $2^{-/-}$mice might be especially important for the progression to diabetes, as Pdx1 regulates components of the glucose sensing pathway, and pathological processes that reduce $P d x 1$ expression cause glucose intolerance $(11,15)$.

To test the role of Pdx1 in Irs $2^{-/-}$mice, we intercrossed Irs $2^{+/-}$mice with $P d x 1^{+/-}$mice and backcrossed the compound heterozygotes to produce the nine expected genotypes at mendelian frequencies (8). On P2.5, haploinsufficiency for $P d x 1$ or Irs 2 had no effect on body weight, whereas Irs $2^{-/-}$mice were slightly smaller by comparison with littermates (Figure 2a). Irs $2^{-/-} P d x 1^{+/-}$ mice and mice lacking $P d x 1\left(P d x 1^{-/-}, \operatorname{Irs} 2^{+/-} P d x 1^{-/-}\right.$, or Irs $\left.2^{--} P d x 1^{-/-}\right)$were about $40 \%$ smaller at $\mathrm{P} 2.5$ and failed to gain weight thereafter (Figure 2a and data not shown). During the first 5 postnatal days, most mice displayed normal blood glucose, including the Irs $2^{-/-}$ and $P d x 1^{-/-}$mice (Figure $2 \mathrm{~b}$ ). However, Irs $2^{-/} P d x 1^{+/-}$ mice developed severe hyperglycemia and died by P4; Irs $2^{-/} P d x 1^{-/-}$mice displayed a similar outcome (Figure $2 \mathrm{c}$ and data not shown). No sexual dimorphism was seen in the Irs2 $2^{-/} P d x 1^{+/-}$mouse phenotypes, as both

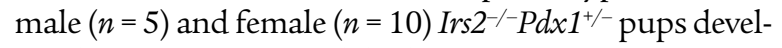
oped hyperglycemia and died by P4. By contrast, $P d x 1^{-/-}$ mice displayed normal blood glucose at P2.5 and survived for up to 9 days, suggesting that Irs2 signaling might promote neonatal glucose homeostasis without insulin (Figure 2b). As shown previously, Irs $2^{-/-}$mice a

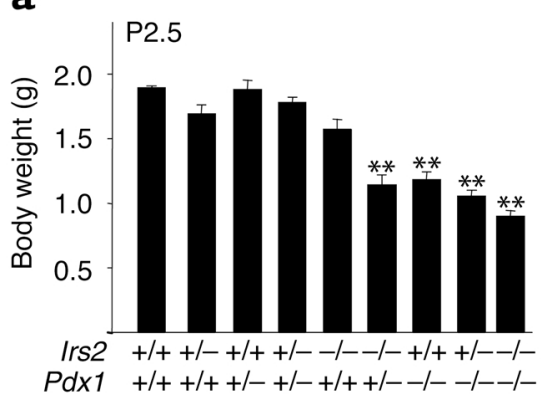

b

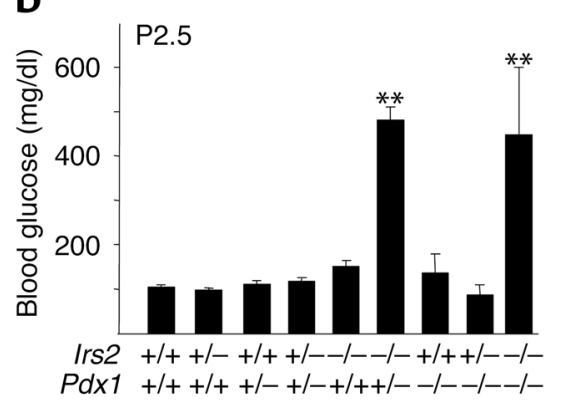

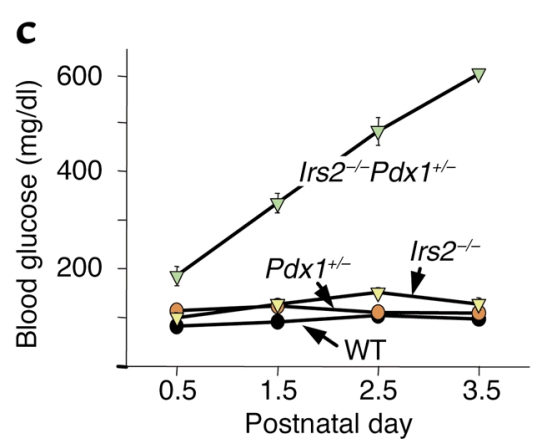

C

Figure 2

Characterization of progeny of Irs $2^{+/-P} d x 1^{+/-}$intercross. (a) Body weights of Irs $2^{+/-P} d x 1^{+/-}$intercross pups measured on P2.5. Results are reported as mean \pm SEM of at least seven mice (except Irs $2^{-/-} P d x 1^{-/-}$mice, $n=3$ ). ${ }^{* *} P<0.01$ compared with all other genotypes. (b) Blood glucose of Irs $2^{+/-} P d \times 1^{+/-}$intercross pups measured on P2.5. Results are reported as mean \pm SEM of at least seven mice, or three Irs $2^{-/-} P d x 1^{-/-}$ mice. ${ }^{*} P<0.01$ for Irs $2^{-/-} P d x 1^{+/-}$or Irs $2^{-/-} P d x 1^{-/-}$mice compared with all other genotypes. (c) Blood glucose values of wild-type, Irs2 ${ }^{-/-}$, $P d x 1^{+-}$, and Irs2 $2^{-/-} P d x 1^{+-}$mouse pups in the first 4 days of life. Results are reported as mean \pm SEM of at least seven mice. 
a
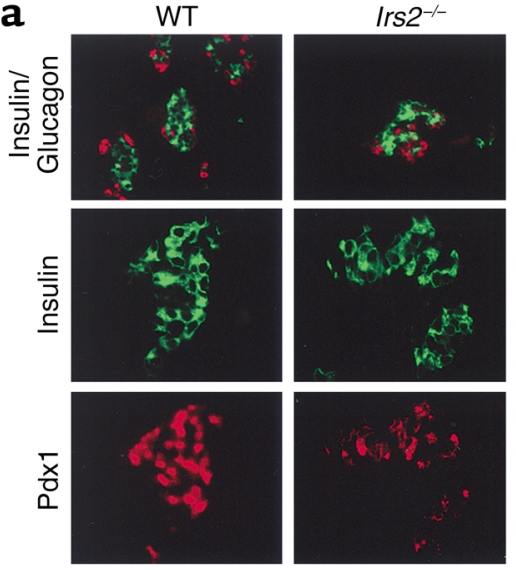

b

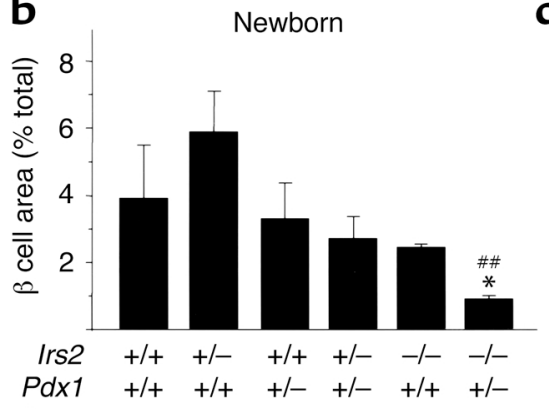

d

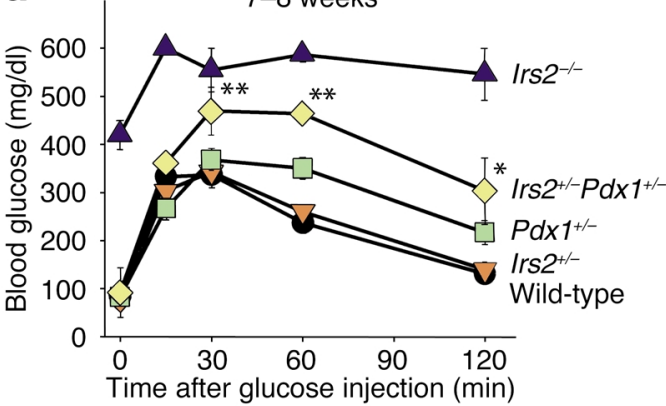

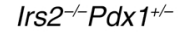
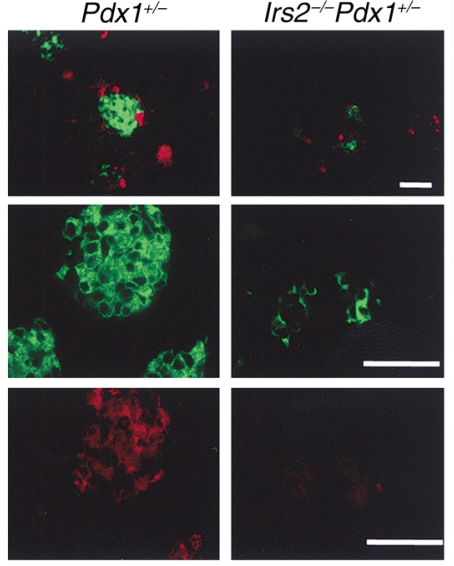

c

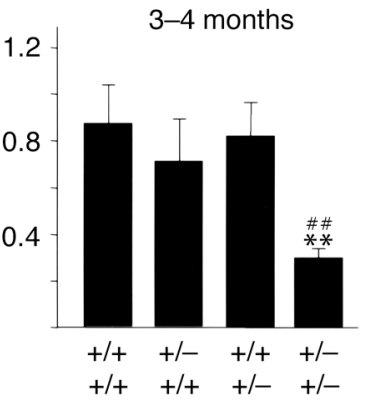

Figure 3

Islet morphology and quantification from $I r s 2^{+/-} P d x 1^{+/-}$ intercross mice and glucose tolerance tests of adult Irs $2^{+/-} P d x 1^{+/-}$intercross mice. (a) Representative islet morphology from pancreas of newborn Irs $2^{+/-P} d x 1^{+/-}$ intercross pups immunostained with antibodies against insulin (green) and glucagon (red, top panels), insulin (green, middle panels), and Pdx1 (red, bottom panels). Scale bars, $50 \mu \mathrm{m}$. (b) $\beta$ Cell area of newborn male and female progeny from $\operatorname{Irs} 2^{+/-P} d \times 1^{+/-}$intercross pups (mean \pm SEM relative to total pancreas area). Irs $2^{-/-} P d x 1^{+/-}$pups have decreased $\beta$ cell area compared with wild-type, Irs2 $2^{-/-}$, or $P d x 1^{+/-}\left({ }^{*} P<0.05,{ }^{\# \#} P<0.01\right)$. (c) Morphometric analysis of pancreas sections of 3- to 4-month-old male progeny from the $I r s 2^{+/-} P d \times 1^{+/-}$intercross. Results are reported as mean \pm SEM of $\beta$ cell area (percent relative to total pancreas area). At 3-4 months, Irs $2^{+/-} P d x 1^{+/-}$mice have decreased $\beta$ cell area compared with wild-type $\left({ }^{*} P<0.01\right)$ or $P d \times 1^{+/-}$ $\left({ }^{\#} P<0.01\right)$. (d) Glucose tolerance tests of 7- to 8-weekold mice performed with $2 \mathrm{~g}$ D-glucose per $\mathrm{kg}$ body weight after a 15- to 16-hour fast (wild-type, $n=6$; Irs $2^{+/-}, n=11 ; P d x 1^{+/-}, n=9 ; \operatorname{Irs} 2^{+/-} P d x 1^{+/-}, n=11 ;$ Irs $2^{+/-} P d x 1^{+/-}, n=17 ;$ Irs $\left.2^{-/-}, n=4\right)$. Results are reported as mean \pm SEM. ${ }^{*} P<0.05$, Irs $2^{+/-} P d x 1^{+/-}$vs. $P d x 1^{+/-}$; ${ }^{*} P<0.01, \operatorname{Irs} 2^{+/-} P d x 1^{+/-}$vs. $P d \times 1^{+/-}$. developed fasting hyperglycemia at 8 weeks and died between 12 and 15 weeks of age $(2,7)$.

Pancreas sections were immunostained with antibodies against insulin and glucagon to characterize islet histology and estimate pancreatic $\beta$ cell content. As expected, the pancreas failed to develop in mice lacking $P d x 1$, including $\operatorname{Irs} 2^{+/-} P d x 1^{-/-}$and $\operatorname{Irs} 2^{-/-} P d x 1^{-/-}$ mice; however, it developed in proportion to body size in the other mice (data not shown). At birth,

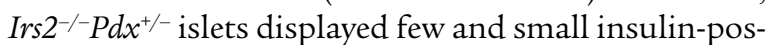
itive $\beta$ cell clusters, compared with the normal-sized islets in Irs2 $2^{--}, P d x 1^{+/-}$, and wild-type mice (Figure 3a). Pdx1 immunostaining was readily detected in wild-type islets but was consistently reduced in $\mathrm{Pdx}^{+/-}$and in Irs $2^{-/-}$islets; and it was nearly undetected in Irs $2^{-/-} P d x 1^{+/-}$islets, consistent with the severe hyperglycemia that developed at birth (Figure 3a).

$\beta$ Cell content was quantified in the various mice by estimating the insulin-positive area in multiple pancreatic sections. Compared with wild-type mice, $\beta$ cell content was slightly increased in newborn $\operatorname{Irs} 2^{+/-}$mice and slightly decreased in $P d x 1^{+/-}, P d x 1^{+/-} \operatorname{Irs} 2^{+/-}$, and Irs $2^{-/-}$mice; however, these small changes did not reach statistical significance (Figure $3 b$ ). By contrast, $\beta$ cell content was significantly reduced in pancreatic slices from newborn Irs $2^{-/-} P d x^{+/-}$mice $(P<0.05)$, consistent with the onset of fatal hyperglycemia 4 days after birth (Figure $3 b)$. By 3-4 months of age, $\beta$ cell content was similar in Irs2 ${ }^{+/-}$, wild-type, and $P d x 1^{+/-}$ mice (Figure $3 c$ ); however, $\beta$ cell content was reduced by $75 \%$ in compound heterozygous $\operatorname{Irs} 2^{+/-} P d x 1^{+/-}$mice, suggesting that both Irs 2 and Pdx1 contribute to normal islet function (Figure 3c). Consequently, $\operatorname{Ir} s 2^{+/-} P d x 1^{+/-}$mice displayed more severe glucose intolerance than did less affected littermates at 7-8 weeks of age (Figure 3d).

To test whether $\mathrm{Pdx} 1$ promotes normal function of Irs $2^{-/} \beta$ cells, we crossed Irs $2^{+/-}$mice with $P d x 1^{\text {tg }}$ mice to increase the $P d x 1$ gene dosage in the Irs $2^{-/-}$mice. As previously described, $P d x 1^{\text {tg }}$ mice have multiple copies of a rat $P d x 1$ cDNA controlled by the rat $P d x 1$ promoter, which results in approximately threefold Pdx1 overex- 
pression in the appropriate locations and developmental stages (16). Random-fed glucose and insulin levels were identical in wild-type and $P d x 1^{t y}$ mice (Figure 4, a and b). Remarkably, $P d x 1^{t g}$ expression prevented the hyperglycemia and relative hypoinsulinemia that developed in Irs $2^{-/-}$mice during the first 12-13 weeks of life (Figure 4 , $\mathrm{a}$ and $\mathrm{b}$ ). Moreover, Irs $2^{-/-} P d x 1^{\text {tg }}$ mice survived with nearly normal glucose and insulin levels for up to 16 months; we now have Irs $2^{--P}-P 1^{\text {tg }}$ mice that have survived with mild glucose intolerance for up to 20 months. Based on these results, the $P d x 1^{\text {tg }}$ expression restored $\beta$ cell function in Irs $2^{-/}$mice and prevented the development of diabetes.

Although $P d x 1^{\text {tg }}$ expression promoted $\beta$ cell function in $I r s 2^{-/-}$mice, it had no significant effect on the sensitivity of wild-type mice to exogenous insulin injections and only slightly restored responsiveness of $\operatorname{Irs} 2^{-1-P d x 1^{\text {tg }}}$ mice to insulin injections (Figure 4c). Glucose tolerance at 12-13 weeks of age was significantly improved in Irs $2^{-/-} P d x 1^{\text {tg }}$ mice compared with Irs $2^{-/-}$mice; however, tolerance was not entirely corrected, possibly owing to persistent peripheral insulin resistance (Figure $4 \mathrm{~d}$ ). Irs $2^{-/-}$mice develop various disorders, including impaired brain and retinal growth, and infertility in females, and these defects persisted in Irs $2^{-/} P d x 1^{\text {tg }}$ mice, suggesting that they are a result of dysregulated Irs2 signaling rather chronic hyperglycemia or diabetes (M. Schubert et al., manuscript submitted for publication; and ref. 18).

Transgenic expression of $P d x 1$ had profound effects on the histology of Irs $2^{-/}$islets. At 4-5 weeks of age, immunostaining of insulin and Pdx1 in Irs $2^{---}$islets was consistently reduced compared with that of wild-type mice (Figure 5). By contrast, insulin and Pdx1 immunostaining was consistently strong in $P d x 1^{\text {tg }}$ and

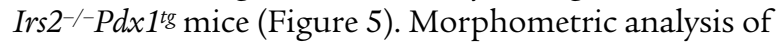
pancreatic sections at 4-5 weeks and at 3-4 months of age confirmed that $\beta$ cell content (approximated by the mean cross-sectional $\beta$ cell area) was significantly reduced in Irs $2^{-/-}$mice (Table 1). $P d x 1^{\text {tg }}$ expression did not change $\beta$ cell content in wild-type pancreas sections,

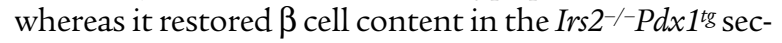
tions (Table 1). Moreover, $P d x 1^{\text {tg }}$ expression increased the $\beta$ cell $/ \alpha$ cell ratio in wild-type and Irs $2^{-/-}$mice, especially at $3-4$ months of age (Table 1 ). Although $\beta$ cell content in Irs $2^{-/-}$sections decreased with age, the number of islets detected was barely reduced, and $P d x 1^{\text {tg }}$ expression preserved or slightly increased the number of islets detected in the pancreas sections (Table 1). Thus, $P d x 1^{\text {tg }}$ expression largely restores islet morphology in $I r s 2^{-/-}$mice.

Since the size of $\beta$ cells was barely affected by the absence of Irs 2 or the presence of $P d x 1^{\text {tg }}$ (Table 1 ), the increased $\beta$ cell content in $P d x 1^{\text {tg }}$ mice pancreas might be related, at least in part, to increased mitogenesis. Mitogenesis was estimated by the incorporation during 6 hours of BrdU into $\beta$ cells of 2 - to 3 -week-old male mice. BrdU labeling of Irs2 $2^{-1} \beta$ cells was decreased about $40 \%$ compared with wild-type mice, consistent with decreased $\beta$ cell content. By contrast, BrdU labeling was increased twofold in both $P d x 1^{\text {tg }}$ and Irs $2^{-/} P d x 1^{\text {tg }}$ mice (Figure 6). Thus, Pdx1-mediated mitogenesis might contribute to increased $\beta$ cell content of $\operatorname{Irs} 2^{-/-}$mice. a

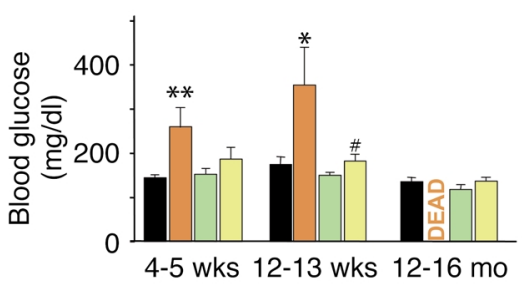

c

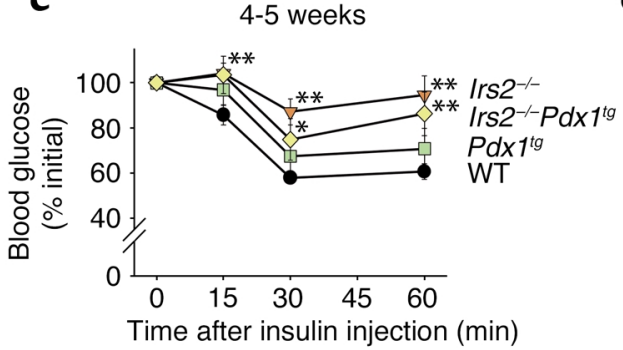

b
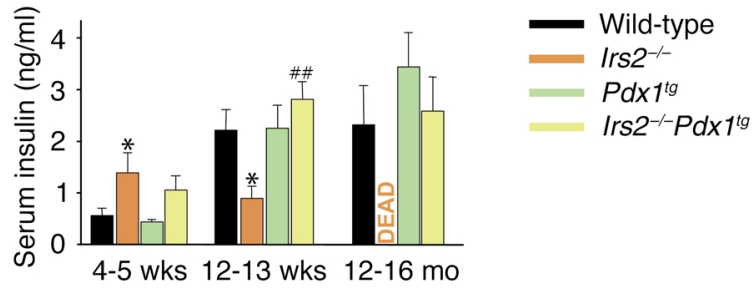

d

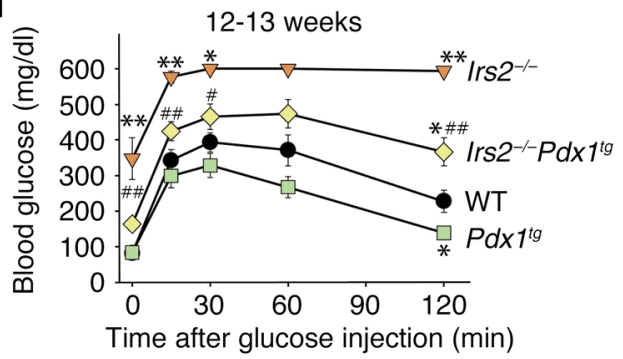

Figure 4

Characterization of male progeny of $I r s 2^{+/-} P d x 1^{t g}$ intercross. ( $\mathbf{a}$ and $\left.\mathbf{b}\right)$ Random-fed blood glucose (a) and serum insulin (b) of $I r s 2^{+/-} P d x 1^{t g}$ intercross mice at 4-5 weeks, $12-13$ weeks, and 12-16 months. Results are mean \pm SEM of six mice per genotype. ${ }^{*} P<0.05$, Irs2 ${ }^{-/-}$vs. wildtype; ${ }^{*} P<0.01$, Irs $2^{-/-}$vs. wild-type; ${ }^{*} P<0.05$, Irs $2^{-/-} P d x 1^{\text {tg }}$ vs. Irs $2^{-/-}$; ${ }^{\# \#} P<0.01$, Irs $2^{-/-} P d x 1^{\text {tg }}$ vs. Irs2 $2^{-/-}$. (c) Insulin tolerance test of 4- to 5week-old fed mice performed with $0.75 \mathrm{U} / \mathrm{kg}$ human regular insulin on fed animals. Results are expressed as mean $\pm \mathrm{SEM}$ of percent of initial blood glucose value for at least eight animals per genotype. ${ }^{*} P<0.05$ and ${ }^{*} P<0.01$ vs. wild-type. (d) Glucose tolerance tests of 12 - to 13-week-old mice performed with $2 \mathrm{~g}$ D-glucose per $\mathrm{kg}$ body weight after a 15 - to 16-hour fast. Results reported as mean \pm SEM for at least eight animals per genotype. ${ }^{*} P<0.05$ vs. wild-type; ${ }^{*} P<0.01$ vs. wild-type; ${ }^{\# \#} P<0.01, \operatorname{Irs} 2^{-/-} P d x 1^{\text {tg }}$ vs. Irs $2^{-/-}$. 

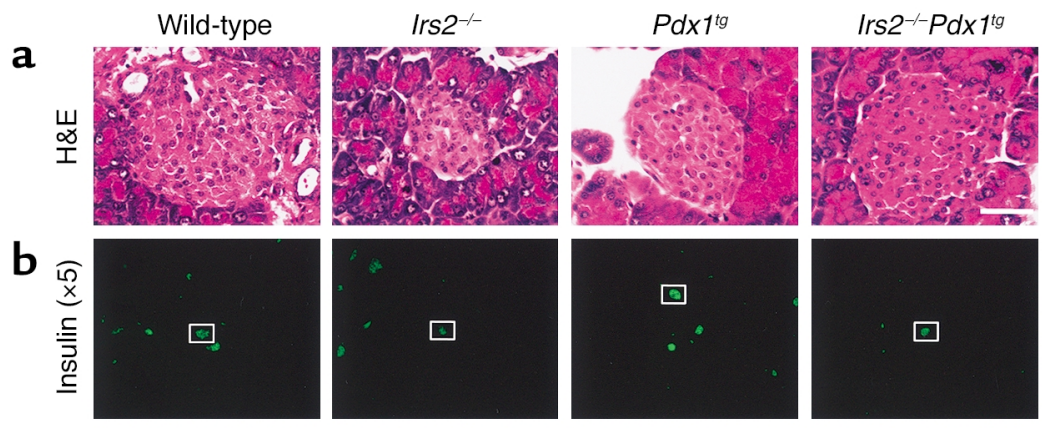

\section{Figure 5}

Islet morphology of male Irs $2^{+/-} P d x 1^{\text {tg }}$ intercross mice. Representative pancreas sections from 4- to 5-week-old Irs $2^{+/-} P d x 1^{\text {tg }}$ intercross mice. (a) Hematoxylin-and-eosin ( $\mathrm{H} \& \mathrm{E})$ staining at $\times 63$. (b and $\mathbf{c}$ ) Immunostaining with antibodies against insulin, photographed at $\times 5$ (b) and $\times 63$ (c). (d) Immunostaining with antibodies against $\mathrm{Pdx} 1$. (e) Immunostaining with antibodies against insulin (green) and glucagon (red). Scale bars, $50 \mu \mathrm{m}$.
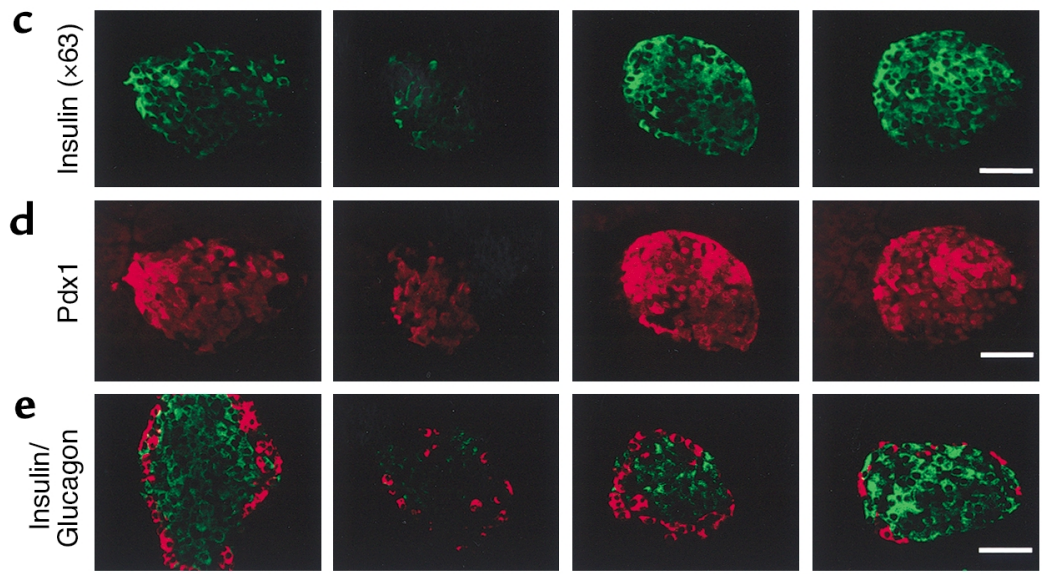

\section{Discussion}

Our results show that the progressive loss of $\beta$ cell function and the onset of diabetes in Irs $2^{-/-}$mice are associated with decreased expression in pancreatic islets of the homeodomain transcription factor $P d x 1$ (also called $I d x-1$ and Ipf1). PDX1 is critical for the development of the pancreas in mice and people, and pancreas agenesis occurs upon the complete disruption of PDX1 $(7,19)$. Moreover, PDX1 is required in adult humans and mice to promote normal glucose sensing and insulin secretion $(13,15)$. Genetic defects in the PDX1 gene occur in about $5 \%$ of people with type 2 diabetes. Inactivating mutations are associated with autosomal early-onset diabetes (MODY), whereas missense mutations predispose humans to late-onset type 2 diabetes $(14,20)$.

The functional association between Irs 2 signaling and $\mathrm{Pdx} 1$ expression observed in mice might relate type 2 diabetes to autosomal forms of diabetes (MODY). Genetic reduction of $P d x 1$ in Irs $2^{-/-}$mice causes diabetes at birth owing to severe reduction of islet $\beta$ cell content. By contrast, transgenic expression of $P d x 1$ postpones $\beta$ cell failure and prevents the progression of Irs $2^{-/-}$mice to diabetes. Partial reduction of both genes in $\operatorname{Irs} 2^{+/-} P d x 1^{+/-}$mice causes an intermediate phenotype of severe glucose intolerance. If insulin resistance in people includes an IRS2 component, diminished IRS2 signaling might reduce PDX1 function and eventually impair $\beta$ cell compensation, resulting in type 2 diabetes. Moreover, genetic defects in PDX1 might exacerbate the effects of insulin resistance, even if the defects alone are physiologically silent until challenged by the need for a compensatory response. By contrast, people with robust
PDX1 function might avoid diabetes even during chronic insulin resistance.

While mutations in PDX1 are associated with human diabetes, naturally occurring IRS2 mutations are very rare $(21,22)$. However, physiological stress associated with acute injury, chronic obesity, inactivity, or aging promotes peripheral insulin resistance. Recent evidence suggests that serine phosphorylation or regulated degradation of Irs proteins might contribute to this insulin resistance $(23,24)$. If functional dysregulation of IRS2 extends to $\beta$ cells, the ability to compensate for peripheral insulin resistance by increasing $\beta$ cell mass and insulin secretion might be impaired and lead to glucose intolerance and diabetes. A related mechanism could contribute to type 1 diabetes, where proinflammatory cytokines produced by infiltrating

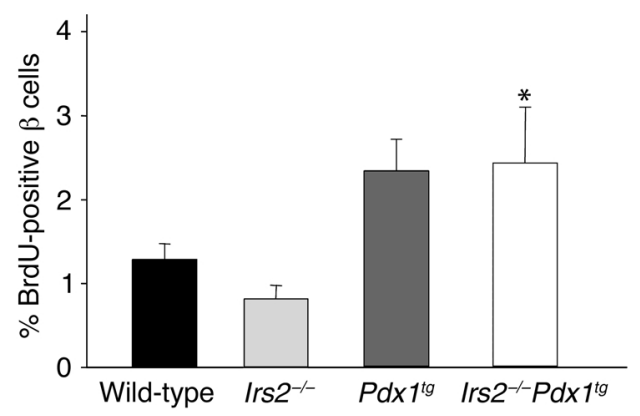

\section{Figure 6}

BrdU incorporation analysis of male Irs $2^{+/-} P d x 1^{\text {tg }}$ intercross progeny at 2-3 weeks of age. Results are reported as percent BrdU-positive $\beta$

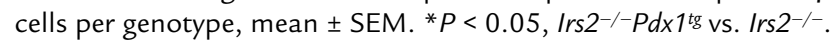


Table 1

Islet morphometry of Irs2 ${ }^{+/-P d x} 1^{\text {tg }}$ intercross mice

\begin{tabular}{|c|c|c|c|c|c|c|c|c|c|c|c|c|}
\hline \multirow[t]{3}{*}{ Genotype } & \multicolumn{4}{|c|}{$\begin{array}{c}\beta \text { Cell Area } \\
\text { (\% total) }\end{array}$} & \multicolumn{4}{|c|}{$\begin{array}{c}\text { Islet Size } \\
\left(\mu \mathrm{m}^{2} \times 10^{3} / \text { islet }\right)\end{array}$} & \multicolumn{4}{|c|}{$\begin{array}{l}\text { Islet Density } \\
\text { (islets } / \mu \mathrm{m}^{2} \text { ) }\end{array}$} \\
\hline & \multicolumn{2}{|c|}{ 4-5 weeks } & \multicolumn{2}{|c|}{ 3-4 months } & \multicolumn{2}{|c|}{ 4-5 weeks } & \multicolumn{2}{|c|}{$3-4$ months } & \multicolumn{2}{|c|}{ 4-5 weeks } & \multicolumn{2}{|c|}{ 3-4 months } \\
\hline & & $P$ & & $P$ & & $P$ & & $P$ & & $P$ & & $P$ \\
\hline Wild Type & $0.51 \pm 0.07$ & & $0.83 \pm 0.19$ & & $3.1 \pm 0.4$ & & $4.8 \pm 0.5$ & & $1.3 \pm 0.1$ & & $1.4 \pm 0.1$ & \\
\hline Irs2-/- & $0.26 \pm 0.06$ & 0.01 & $0.32 \pm 0.04$ & 0.01 & $2.5 \pm 0.3$ & 0.21 & $2.1 \pm 0.2$ & $<0.01$ & $0.8 \pm 0.1$ & 0.02 & $1.3 \pm 0.1$ & 0.22 \\
\hline$P d x 1^{\text {tg }}$ & $0.60 \pm 0.06$ & 0.38 & $1.30 \pm 0.25$ & 0.28 & $2.8 \pm 0.3$ & 0.4 & $3.9 \pm 0.3$ & 0.11 & $1.8 \pm 0.1$ & 0.02 & $2.8 \pm 0.4$ & $<0.01$ \\
\hline Irs $2^{-/-} P d x 1^{\operatorname{tg}}$ & $0.44 \pm 0.05$ & 0.04 & $0.80 \pm 0.31$ & 0.04 & $2.0 \pm 0.2$ & 0.2 & $4.6 \pm 0.8$ & $<0.01$ & $1.8 \pm 0.3$ & 0.01 & $1.4 \pm 0.3$ & 0.49 \\
\hline \multirow[t]{3}{*}{ Genotype } & \multicolumn{4}{|c|}{$\beta / \alpha$-Cell Ratio } & \multicolumn{3}{|c|}{$\begin{array}{l}\beta \text { Cell Size } \\
\left(\mu \mathrm{m}^{2} / \text { islet }\right)\end{array}$} & & & & & \\
\hline & \multicolumn{2}{|c|}{ 4-5 weeks } & \multicolumn{2}{|c|}{ 3-4 months } & \multicolumn{3}{|c|}{$2-3$ weeks } & & & & & \\
\hline & \multicolumn{2}{|c|}{$P$} & & $P$ & \multicolumn{3}{|c|}{$P$} & & & & & \\
\hline Wild Type & $4.9 \pm 0.6$ & & $17.2 \pm 2.1$ & & $108 \pm 6$ & & & & & & & \\
\hline $\operatorname{lrs} 2^{-/-}$ & $4.1 \pm 1.0$ & 0.53 & $5.6 \pm 1.8$ & $<0.01$ & $96 \pm 7$ & $0.2 S$ & & & & & & \\
\hline$P d \times 1^{\text {tg }}$ & $8.5 \pm 0.9$ & 0.02 & $23.9 \pm 2.2$ & 0.07 & $107 \pm 8$ & 0.91 & & & & & & \\
\hline $\operatorname{Irs} 2^{-/-} P d \times 1^{\operatorname{tg}}$ & $8.3 \pm 1.3$ & 0.03 & $28.2 \pm 10.8$ & 0.08 & $118 \pm 3$ & 0.03 & & & & & & \\
\hline
\end{tabular}

Morphometric $\beta$ cell area analysis of male Irs $2^{+-}-P d x 1^{t g}$ intercross progeny at $4-5$ weeks and 3 months of age. $\beta$ Cell area was calculated from the mean crosssectional $\beta$ cell area of pancreas, reported as \% of total pancreas area. Islet size was calculated from the mean cross-sectional $\beta$ cell area per islet, reported as $\mu \mathrm{m}^{2} \times 10^{3} /$ islet. Islet density was calculated from the mean islet density of pancreas, reported as islets $/ \mu \mathrm{m}^{2} . \beta / \alpha$-Cell ratio was calculated as the mean crosssectional $\beta / \alpha$-cell area ratio. $\beta$ Cell size was calculated from the mean cross-sectional $\beta$ cell size, reported as $\mu \mathrm{m}^{2} /$ islet. Irs $2^{-/-} P$ values against wild-type, $P d x 1^{\text {tg }}$ $P$ values against wild-type, Irs $2^{-/-P d x} 1^{\text {tg }} P$ values against Irs $2^{-/-}$.

lymphocytes could inactivate Irs protein signaling and accelerate $\beta$ cell death (25).

IRS-proteins coordinate multiple downstream signals through the PI 3-kinase and ERK1/2 cascades (26). Both pathways are regulated by Irs 1 or Irs 2 , and both Irs proteins are expressed in $\beta$ cells; however the Irs 2 branch appears to be most important in mice (27). Irs proteins contain similar but not identical pleckstrin homology $(\mathrm{PH})$ and phosphotyrosine-binding domains at their $\mathrm{NH}_{2}$-terminus that mediate coupling with activated membrane receptors. Cell-based experiments have not revealed a specificity that could explain the functional selectivity observed for Irs 2 in $\beta$ cells. However Irs 2 interacts with the activated kinase regulatory loop of the insulin receptor, revealing a unique mechanism for coupling that is not shared with Irs1 (28). By contrast, the $\mathrm{PH}$ domain in Irs1 binds to PHIP, a protein that might contribute unique specificity (29).

The Irs $2 \rightarrow$ PI 3-kinase cascade controls many downstream elements, including Akt/protein kinase $\mathrm{B}, \mathrm{p} 70^{\mathrm{s} 6 \mathrm{k}}$, $\mathrm{BAD} / \mathrm{Bcl} 2$, and the Foxo subfamily of transcription factors (30). Recently Akt 1 and $\mathrm{p} 70^{\text {skk }}$ were shown to promote $\beta$ cell growth and function in mice, supporting the importance of signaling components regulated in $\beta$ cells by the Irs $2 \rightarrow$ PI 3 -kinase cascade $(31,32)$. One way that Akt promotes survival of cells is by phosphorylation of $\mathrm{BAD}$, which promotes the dissociation of active Bcl2 (33). Since apoptosis of $\beta$ cells might be crucial at several points during the onset of type 1 or type 2 diabetes, BAD phosphorylation stimulated by the Irs $2 \rightarrow$ PI 3-kinase $\rightarrow$ Akt cascade might be an important signal for $\beta$ cell survival $(34,35)$. Previous reports show that Irs $2^{-1-} \beta$ cells undergo increased apoptosis at weaning, which might contribute to the early loss of $\beta$ cell mass (4); however, we did not investigate the effect of $P d x 1$ expression on apoptosis during weaning and did not detect apoptosis at later ages.

$\mathrm{Pd} 1$ expression and function might be entirely independent of Irs 2 signaling and reduced in Irs $2^{-/-}$islets owing to $\beta$ cell progressive failure. In this case, transgenic expression of $P d x 1$ could overcome the negative effects of the Irs 2 knockout by strongly promoting the expression of genes that are essential for $\beta$ cell function $(10,11)$. However, our results are consistent with the hypothesis that Irs2-signaling directly regulates expression and function of Pdx1. Preliminary evidence suggests that $P d x 1$ expression in $\beta$ cells is repressed through nuclear localization of the transcription factor Foxo1 (also called FKHR) (36). Foxo1 is ordinarily exported from the nucleus and retained in the cytosol by Akt-mediated phosphorylation (33). However, Foxo1 is largely nuclear in

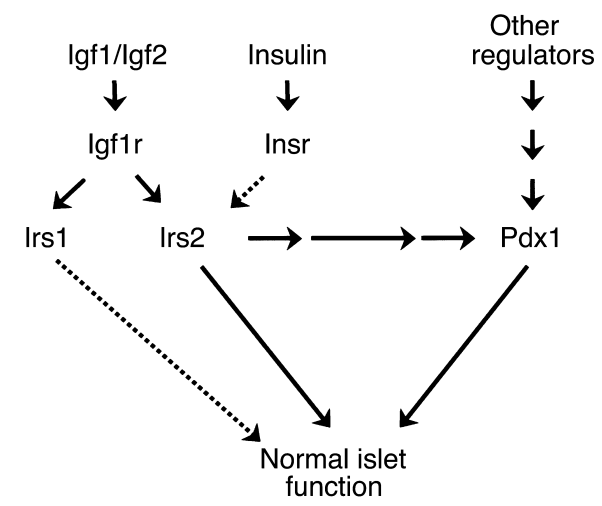

Figure 7

Proposed model of the multiple pathways linking Irs2 signaling and Pdx1 action in $\beta$ cells. 
Irs $2^{-/} \beta$ cells, consistent with the relative inactivity of the PI 3-kinase $\rightarrow$ Akt cascade (36). Interestingly, disruption of a single Foxo1 allele reduces the level of nuclear Foxo1 in Irs $2^{--} \beta$ cells, which increases $P d x 1$ expression and restores sufficient $\beta$ cell function to normalize glucose homeostasis (36). More details about the integration of $\beta$ cell transcription factors with the Irs 2 branch of the insulin/Igf signaling cascade might reveal new strategies to promote $\beta$ cell growth and function in both type 1 and type 2 diabetes (Figure 7).

$P D X 1$ is critical for the development of the pancreas, and pancreas agenesis occurs upon the complete disruption of $P D X 1$ in mice and humans $(7,19)$. Although Pdx1 levels are low in Irs $2^{-/-}$mice and lower in the Irs $2^{-/-} P d x 1^{+/-}$mice, the exocrine pancreas develops normally unless $P d x 1$ is completely disrupted. During early development, $P d x 1$ expression might be largely independent of Irs2 signaling, whereas after birth $P d x 1$ might be regulated by Irs2-dependent and -independent mechanisms (Figure 7). The hepatocyte nuclear factor $\mathrm{Hnf} 3 \beta$ promotes expression of $P d x 1$, so its reduced expression in Irs $2^{-/-} \beta$ cells might contribute to their failure $(6,37)$. However, genetic disruption of $H n f 3 \beta$ in $\beta$ cells causes hyperinsulinemia at birth, possibly owing to the reduced expression of the ATP-sensitive potassium channel in $\beta$ cells (38). So Hnf $3 \beta$ might not be an essential element for $P d x 1$-mediated $\beta$ cell function. The interaction of these related transcription factors and their integration with receptor signaling are an important direction of future work.

At the physiological level, the relation between Irs 2 signaling and Pdx 1 function is supported by the common development of diabetes between 10 and 15 weeks of age in Irs $2^{-/-}$mice, or in mice lacking $\beta$ cell $P d x 1(2,13)$. The progressive dysfunction of $\beta$ cells specifically lacking $P d x 1$ is related to the reduced expression of genes that promote glucose-sensitive insulin secretion, including proinsulin, glucose transporter-2, glucokinase, and components of the FGF receptor signaling system that control prohormone convertase $1 / 3$ expression (10-12). Consistent with the relation between Irs 2 and Pdx1, these gene products were always detected weakly by immunostaining Irs $2^{-/-} \beta$ cells, whereas they were

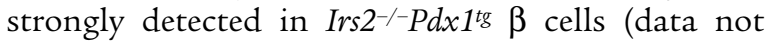
shown). These preliminary results are consistent with the hypothesis that $P d x 1$ mediates many of the effects of Irs 2 on $\beta$ cell function.

Irs $2^{-/-} P d x 1^{+/-}$and Irs $2^{-/-} P d x 1^{-/-}$mice were hyperglycemic at birth, owing apparently to the near absence of $\beta$ cells or the absence of a pancreas, respectively. However, $P d x 1^{-/-}$mice were euglycemic until P4, suggesting that extrapancreatic ligands might regulate neonatal glucose homeostasis through Irs2. The importance of Irs2 at this stage is consistent with its role in hepatocytes to mediate the inhibitory effects of insulin on gluconeogenesis (3).

Based on our results we conclude that the Irs 2 branch of the insulin/Igf signaling pathway is important for the growth and function of murine $\beta$ cells. Many of the effects of Irs 2 , including $\beta$ cell growth and function are closely associated with $P d x 1$ expression. Our results are consistent with a direct link between Irs2 and Pdx1 expression and function; however, additional experiments using cell-based strategies are necessary to prove this hypothesis. Our experiments provide a starting point to understand the relation between $\beta$ cell failure and states of chronic insulin resistance. Moreover, dysregulation of $P d x 1$ by genetic or functional mechanisms might be one of the common links between early-onset (MODY) and ordinary type 2 diabetes.

\section{Acknowledgments}

This work was supported by grants from the NIH and the Howard Hughes Medical Institute funds. J.A. Kushner was supported by a Lawson Wilkins Pediatric Endocrine Society Fellowship, a National Institute of Diabetes and Digestive and Kidney Diseases training grant, and a Juvenile Diabetes Research Foundation Fellowship. J. Ye was supported by a Juvenile Diabetes Research Foundation Fellowship.

1. Yenush, L., and White, M.F. 1997. The IRS-signaling system during insulin and cytokine action. Bioessays. 19:491-500.

2. Withers, D.J., et al. 1998. Disruption of IRS-2 causes type 2 diabetes in mice. Nature. 391:900-904.

3. Previs, S.F., Withers, D.J., Ren, J.M., White, M.F., and Shulman, G.I. 2000. Contrasting effects of IRS-1 vs. IRS-2 gene disruption on carbohydrate and lipid metabolism in vivo. J. Biol. Chem. 275:38990-38994.

4. Withers, D.J., et al. 1999. Irs- 2 coordinates Igf- 1 receptor-mediated betacell development and peripheral insulin signalling. Nat. Genet. 23:32-40.

5. Fajans, S.S., Bell, G.I., and Polonsky, K.S. 2001. Molecular mechanisms and clinical pathophysiology of maturity-onset diabetes of the young. N. Engl. J. Med. 345:971-980.

6. Duncan, S.A., Navas, M.A., Dufort, D., Rossant, J., and Stoffel, M. 1998. Regulation of a transcription factor network required for differentiation and metabolism. Science. 281:692-695.

7. Jonsson, J., Carlsson, L., Edlund, T., and Edlund, H. 1994. Insulin-promoter-factor 1 is required for pancreas development in mice. Nature. 371:606-609.

8. Offield, M.F., et al. 1996. PDX-1 is required for pancreatic outgrowth and differentiation of the rostral duodenum. Development. 122:983-995.

9. Peers, B., Leonard, J., Sharma, S., Teitelman, G., and Montminy, M.R. 1994. Insulin expression in pancreatic islet cells relies on cooperative interactions between the helix loop helix factor E47 and the homeobox factor STF-1. Mol. Endocrinol. 8:1798-1806.

10. Watada, H., et al. 1996. The human glucokinase gene beta-cell-type promoter: an essential role of insulin promoter factor 1/PDX-1 in its activation in HIT-T15 cells. Diabetes. 45:1478-1488.

11. Waeber, G., Thompson, N., Nicod, P., and Bonny, C. 1996. Transcriptional activation of the GLUT2 gene by the IPF-1/STF-1/IDX-1 homeobox factor. Mol. Endocrinol. 10:1327-1334.

12. Hart, A.W., Baeza, N., Apelqvist, A., and Edlund, H. 2000. Attenuation of FGF signalling in mouse beta-cells leads to diabetes. Nature. 408:864-868.

13. Ahlgren, U., Jonsson, J., Jonsson, L., Simu, K., and Edlund, H. 1998. $\beta$-cell-specific inactivation of the mouse Ipf1/Pdx 1 gene results in loss of the beta-cell phenotype and maturity onset diabetes. Genes Dev. 12:1763-1768.

14. Hani, E.H., et al. 1999. Defective mutations in the insulin promoter factor-1 (IPF-1) gene in late-onset type 2 diabetes mellitus. J. Clin. Invest. 104:R41-R48.

15. Thomas, M.K., et al. 2001. Development of diabetes mellitus in aging transgenic mice following suppression of pancreatic homeoprotein IDX-1. J. Clin. Invest. 108:319-329. DOI:10.1172/JCI200112029.

16. Dutta, S., et al. 2001. PDX:PBX complexes are required for normal proliferation of pancreatic cells during development. Proc. Natl. Acad. Sci. USA. 98:1065-1070.

17. Sutton, R., Peters, M., McShane, P., Gray, D.W., and Morris, P.J. 1986. Isolation of rat pancreatic islets by ductal injection of collagenase. Transplantation. 42:689-691.

18. Burks, D.J., et al. 2000. IRS-2 pathways integrate female reproduction and energy homeostasis. Nature. 407:377-382. 
19. Stoffers, D.A., Zinkin, N.T., Stanojevic, V., Clarke, W.L., and Habener, J.F 1997. Pancreatic agenesis attributable to a single nucleotide deletion in the human IPF1 gene coding sequence. Nat. Genet. 15:106-110.

20. Stoffers, D.A., Ferrer, J., Clarke, W.L., and Habener, J.F. 1997. Early-onset type-II diabetes mellitus (MODY4) linked to IPF1. Nat. Genet. 17:138-139.

21. Bernal, D., et al. 1998. Insulin receptor substrate-2 amino acid polymorphisms are not associated with random type 2 diabetes among Caucasians. Diabetes. 47:976-979.

22. Kalidas, K., et al. 1998. Mapping of the human insulin receptor substrate- 2 gene, identification of a linked polymorphic marker and linkage analysis in families with type 2 diabetes: no evidence for a major susceptibility role. Diabetologia. 41:1389-1391.

23. Rui, L., et al. 2001. Insulin/IGF-1 and TNF- $\alpha$ stimulate phosphorylation of IRS-1 at inhibitory $\mathrm{SER}^{307}$ via distinct pathways. J. Clin. Invest. 107:181-189.

24. Hotamisligil, G.S., and Spiegelman, B.M. 1999. TNF $\alpha$ : a key component of the obesity-diabetes link. Diabetes. 43:1271-1278.

25. Mathis, D., Vence, L., and Benoist, C. 2001. $\beta$-Cell death during progression to diabetes. Nature. 414:792-798.

26. Uchida, T., Myers, M.G., Jr., and White, M.F. 2000. IRS-4 mediates activation of $\mathrm{PKB} /$ Akt during insulin stimulation without inhibition of apoptosis. Mol. Cell. Biol. 20:126-138.

27. Burks, D.J., and White, M.F. 2001. IRS proteins and beta-cell function. Diabetes. 50(Suppl. 1):S140-S145.

28. Sawka-Verhelle, D., Tartare-Deckert, S., White, M.F., and Van Obberghen, E. 1996. Insulin receptor substrate-2 binds to the insulin receptor through its phopshotyrosine-binding domain and through a newly identified domain comprising amino acids 591-786. J. Biol. Chem. 271:5980-5983.

29. Farhang-Fallah, J., Yin, X., Trentin, G., Cheng, A.M., and Rozakis-Adcock, M. 2000. Cloning and characterization of PHIP, a novel insulin receptor substrate-1 pleckstrin homology domain interacting protein.J. Biol. Chem. 275:40492-40497.

30. Saltiel, A.R., and Kahn, C.R. 2001. Insulin signalling and the regulation of glucose and lipid metabolism. Nature. 414:799-806.

31. Tuttle, R.L., et al. 2001. Regulation of pancreatic beta-cell growth and survival by the serine/threonine protein kinase Akt1/PKBalpha. Nat. Med. 7:1133-1137.

32. Pende, M., et al. 2000. Hypoinsulinaemia, glucose intolerance and diminished beta-cell size in S6K1-deficient mice. Nature. 408:994-997.

33. Brazil, D.P., and Hemmings, B.A. 2001. Ten years of protein kinase B signalling: a hard Akt to follow. Trends Biochem. Sci. 26:657-664.

34. Brunet, A., et al. 1999. Akt promotes cell survival by phosphorylating and inhibiting a Forkhead transcription factor. Cell. 96:857-868.

35. Rabinovitch, A., et al. 1999. Transfection of human pancreatic islets with an anti-apoptotic gene (bcl-2) protects beta-cells from cytokine-induced destruction. Diabetes. 48:1223-1229.

36. Kitamura, T., et al. 2001. The transcription factor FKHR promotes beta cell survival in IRS-2 knockout mice. International Symposium on Insulin Receptors and Insulin Action. Geneva, Switzerland. 85 (Abstr.).

37. Gerrish, K., et al. 2000. Pancreatic beta cell-specific transcription of the $\mathrm{pdx}-1$ gene. The role of conserved upstream control regions and their hepatic nuclear factor 3beta sites. J. Biol. Chem. 275:3485-3492.

38. Sund, N.J., et al. 2001. Tissue-specific deletion of Foxa 2 in pancreatic beta cells results in hyperinsulinemic hypoglycemia. Genes Dev. 15:1706-1715. 